\title{
Циркулярно-поляризованная фотолюминесценция в наноструктурах InGaAs/GaAs, дельта-легированных Мn
}

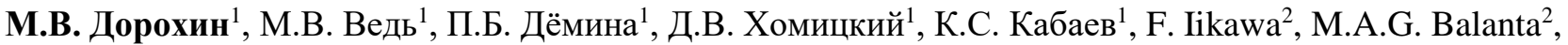 \\ Б.Н. Звонков ${ }^{1}$ \\ ${ }^{1}$ Нижегородский государственныгй университет им. Н.И. Лобачевского, Нижний Новгород, 603950, \\ пр. Гагарина 23/3 \\ ${ }^{2}$ Instituto do Fisica "Gleb Watagin", UNICAMP, 777 Sérgio Buarque de Holanda Street - Cidade \\ Universitária Zeferino Vaz, Barão Geraldo, Campinas, Brazil \\ тел:+7 (962) 507-2122, эл.nочта: dorokhin@nifti.unn.ru
}

DOI $10.34077 / \mathrm{RCSP} 2021-42$

Разбавленные магнитные полупроводники (РМП) занимают важное место в технологиях полупроводниковой спинтроники как материалы, обеспечивающие спиновую поляризацию носителей в приборных структурах [1]. Наиболее изученным видом РМП является (Ga,Mn)As, однако его применение ограничено низкими значениями температуры Кюри ( 110 К) [1]. Для повышения температуры Кюри необходимо повышение содержания Mn в GaAs значительно выше предела растворимости, это возможно за счёт локального дельта-легирования, при котором примесь локализуется в ультратонком слое внутри нелегированного материала.

В частности, ранее нами были сформированы гетероструктуры $\mathrm{InGaAs} / \mathrm{GaAs} /$ дельта $<\mathrm{Mn}>$, в которых дельта-слой Mn выполняет функции ферромагнитного слоя, а близкорасположенная (2-12 нм) к нему квантовая яма InGaAs/GaAs локализует носители заряда [2]. При намагничивании дельта-слоя носители в квантовой яме ориентируются по спину вследствие взаимодействия с ионами Мn. Спиновая поляризация носителей изучается путём измерения циркулярной поляризации фотолюминесценции (ФЛ), возбуждаемой при облучении структуры лазером. В настоящей работе рассмотрен режим облучения структуры последовательно двумя циркулярно-поляризованными импульсами Тісапфирового лазера с разным знаком поляризации. Длина волны лазера составляла 890 нм, что близко по величине к длине волны ФЛ квантовой ямы InGaAs, таким образом было реализовано резонансное возбуждение носителей в квантовой яме.

Как результат воздействия лазерных импульсов, структура испускает циркулярно-поляризованное излучение, степень поляризации которого уменьшается с течением времени. Возбуждающий циркулярно-поляризованный импульс обеспечивает генерацию спин-поляризованных электронов и тяжёлых дырок в квантовой яме. По мере рекомбинации этих носителей протекают процессы спиновой релаксации электронов и дырок с характерными временами $t_{\mathrm{e}}$ и $\mathrm{t}_{\mathrm{h}}$, соответственно, а также процессы взаимодействия спин-поляризованных дырок с ионами $\mathrm{Mn}$, обеспечивающими спиновую поляризацию примесных центров Mn в GaAs [3]. Таким образом, циркулярно-поляризованное лазерное излучение обеспечивает намагничивание ионов $\mathrm{Mn}$ в дельта-слое за счёт взаимодействия с фотовозбуждёнными спин-поляризованными носителями заряда.

Спин-поляризованное состояние $\mathrm{Mn}$ изучалось путём облучения образца вторым лазерным импульсом той же длины волны, но противоположной поляризации. Время задержки между первым и вторым импульсом изменялось от 100 до 2000 пс. Фотовозбуждённые вторым импульсом носители испытывают воздействие ориентированных по спину атомов Mn, что оказывает существенное влияние на динамику спиновой поляризации и на регистрируемые значения степени циркулярной поляризации. В частности, зарегистрировано снижение по абсолютному значению степени циркулярной поляризации по сравнению первым импульсом $(\Delta \mathrm{P})$. Величина $\Delta \mathrm{P}$ зависит от технологических параметров структур, а также от времени задержки между первым и вторым лазерными импульсами. При этом сохранение эффекта даже при задержке в 2000 пс свидетельствует о высоком значении времени спиновой релаксации Мn по сравнению с другими характерными временами системы $\left(\mathrm{t}_{\mathrm{e}} \mathrm{t}_{\mathrm{h}}\right)$. Полученный эффект регистрируется в диапазоне температур 10-40 K, при температуре выше $40 \mathrm{~K}$ значение $\Delta \mathrm{P}$ снижается до уровня погрешности. Значение $\mathrm{T}=40$ К близко к значению температуры Кюри исследованных структур.

Работа выполнена при поддержке Гранта РФФИ №18-29-19137.

\section{Лumepamypa}

[1] D.K. Young, et.al. Semicond. Sci. Tech. 2002. V.17. P.275.

[2] M.V. Dorokhin, et.al. Applied Physics Letters. 2015. V.107. P.028531.

[3] M.A.G. Balanta, et.al. // Nature. Scientific Reports. 2016. V.6. P.24537. 